\title{
HISTORICAL THINKING IN HIGHER EDUCATION
}

\section{STAFF AND STUDENT PERCEPTIONS OF THE NATURE OF HISTORICAL THINKING}

\author{
Adele Nye \\ Correspondence to Adele Nye: Adele.Nye@humn.mq.edu.au \\ Marnie Hughes-Warrington \\ Jill Roe \\ Penny Russell \\ Mark Peel \\ Desley Deacon \\ Amanda Laugeson \\ Paul Kiem
}

Adele Nye was the postdoctoral researcher on the Historical Thinking in Higher Education project. Based at Macquarie University, she has a background in the learning and teaching of history in universities and the subsequent historical practice. Marnie Hughes-Warrington, Pro Vice-Chancellor (Learning and Teaching) at Monash University, led the project and was assisted by the steering committee: Jill Roe (Macquarie University), Penny Russell (University of Sydney), Mark Peel (Monash University), Amanda Laugeson (Flinders University), Desley Deacon (ANU and the Australian Historical Association) and Paul Kiem (The History Teachers' Association of Australia).

\begin{abstract}
This article provides an introduction to the results of a nationwide scoping study of student and staff perceptions of the nature and roles of historical thinking. In 2008-09, over 1400 students and 50 staff from 12 universities around Australia completed interviews and questionnaires. This research report examines student and staff responses to the second questionnaire item, asking for an assessment of the connection between particular activities and historical thinking. The national data reflected a surprisingly consistent pattern of responses and highlighted at least three things which should be of interest and concern to academics: first, students far more than their teachers associated the handling of secondary sources with historical thinking; second, students drew few connections between online work and historical thinking; and third, there were few discernible differences in the responses of introductory and upper-level students. These findings underscore the need for sector-wide work on promoting primary materials work with students, for developing the opportunities provided by computer-assisted learning and articulating and communicating to students the standards of achievement valued by the profession as marking the development of historical thinking at tertiary level.
\end{abstract}

This article has been peer-reviewed.

In the latter part of 2008, 1455 first-year and upper level history students and 50 historians completed interviews and questionnaires on the nature and roles of historical thinking at twelve Australian universities across six states and the Australian Capital Territory. Funded by the Australian Learning and Teaching Council, this scoping study was designed to provide the profession with the information needed to complement and build upon earlier curriculum scoping studies funded by the Australian Historical Association. In particular, the steering committee were interested to know how student and staff perceptions of the discipline might contribute to the increasingly common discussions on national and international standards at tertiary level. 
This paper focuses on student and staff responses to the second item on the questionnaire: a question that asked for ranked connections to be made between particular learning activities and historical thinking. The quantitative data from this question was analysed by a series of statistical categories including national results, academic years, subject areas, individual universities, gender and 'donkey' or blank votes. Students in New South Wales were also asked to indicate if they had studied the History Extension course as part of their Higher School Certificate. The History Extension course is an advanced unit for high school students that builds upon standard history units, introduces them to historiography and historical enquiry and includes an independent research project based on primary sources. This dimension was thought to be of particular value given the current proposal to provide some version of Extension History to students in all states and territories as a part of the National Curriculum. The findings are supported by the qualitative data from interviews with lecturers and the written sections, question one and three, of the student questionnaire. The consistency with which the students ranked particular activities was unexpected and raised questions about their perceptions of evidence, assessment strategies and engagement in a disciplinary dialogue. In some cases, particular groups differed from the national trends and in turn highlighted teaching innovations, progression through the academic years and the impact of having studied History Extension in High School.

\section{BACKGROUND AND METHODOLOGY}

As a preliminary stage of the Historical Thinking in Higher Education project, Matthew Bailey undertook a review of the literature on historical thinking (Bailey and Hughes-Warrington 2009: 14). He highlighted Wineburg's discussion of the engagement with sources (Wineburg 2009), Seixas' description of the engagement and practice of historical study (Seixas 2006), Ashby and Lee's work on empathy (Lee and Ashby 2001), and Levstik's view that historical thinking is a social act rather than an individual one (Levstik 2001). Bailey concluded that evidence-based inquiry is crucial for the development of historical thinking. Where sources are found, interpreted, critiqued and contextualised, and where in turn the student's historical empathy is developed, they learn to engage in a disciplinary conversation. This analysis can be located within Jorn Rüsen's stages of the ontogenetic development of historical consciousness - his traditional, exemplary, critical and genetic categories - and his proposal of a disciplinary construct where orientation of the self and the past can be regarded as a crucial axis for change and intellectual progression for students of history (Rüsen 2005: 11-12). This research has aimed to identify the connections between these theoretical positions and pedagogical debates, with specific examples of historical practice in the higher education setting.

This paper looks at one part of the broader research questions: staff and student perceptions of the specific skills and activities that develop historical thinking. It is part of a series of papers that will reflect both points of agreement and of difference in the profession. This study was an opportunity to look at the epistemological developments in the discipline, and to look at current teaching practices and innovations. The research also reflects a curiosity about the impact of the disciplinary pedagogy on the students' development by identifying the skills used in the construction of, and reflection on, knowledge.

This project utilised many of the qualitative methodologies described by Handel Wright (2006). The formative and data collection processes were based on a collaborative participatory 
action model (Kemmis and McTaggart 2000). They explored situated knowledges (Haraway 1988), the embedded subjective and cultural narratives of the discipline and the knowledge that comes from lived experience in the workplace. The analysis of data used a mixed-method approach. The amount of data demanded quantitative assemblage and traditional empirical analysis.

There were three aspects of the data that may have skewed the results. First, despite clear instructions on how to rank the activities, a surprising number of students chose to assign their own value system to the ratings, selecting numbers 1,2 and 3 and applying them multiple times. Secondly, another group chose to use ticks rather than numbers. All of these responses were not taken into account in the final analysis. Thirdly, the students were given the choice as to how many boxes they numbered. The boxes left unmarked were regarded as 'blanks' in the analysis process. As an absence or a 'non-choice' they do provide another form of data suggesting an activity has not been deemed significant enough to earn a rating. The regularity with which this occurred was unexpected.

Question Two of the survey asked students to rank which activities they felt played a part in the development of their historical thinking. The choices they were given are shown below:

1. Working Online (using the internet or email).

2. Watching and discussing film and television.

3. Reading books and journal articles.

4. Engaging in discussion with academic staff in the classroom.

5. Informal discussions with academic staff outside of the classroom.

6. Engaging in discussion with fellow students outside of the classroom.

7. Engaging in discussion with fellow students in the classroom.

8. Working on an essay or assignment.

9. Receiving feedback on assignments.

10. Making a classroom or online presentation.

11. Attending a lecture.

12. Having conversations with others who have very different opinions or values.

13. Archival work, handling material evidence or engagement in field work

The list of options provided to students did not include the specific terms 'primary' and 'secondary' sources. This may have caused some confusion among students but there was also a concern that students might produce parroted responses - providing answers that they thought may be expected of them, rather than their spontaneous and personal response.

Invitations to participate in the project were sent to 19 Australian universities, of which 12 agreed. The subsequent data offered a broad spectrum of the current body of undergraduate history students and their lecturers on a national scale. Questionnaires were distributed in 40 classes. To date, 50 historians have also been interviewed. Ideally, a larger contribution from the non-eastern Australian states would give a stronger balance to the national picture. In contrast to the way students were provided with a list of activities to rank, academics were invited to describe the particular skills that, through their own experience, promoted students' historical thinking. Staff are identified as belonging to one of three university categories (Table 1): Group of 8 (G8), Innovative Research Universities (IRU) and Independents (Ind). 


\section{NATIONAL TRENDS}

Lecturers were primarily concerned about developing ways to locate and analyse evidence, to understand the idea of context and to appreciate the concept of change. Alongside these were aspects of scholarship, many of which can be also generic higher education teaching and learning goals and mirrored in policy text. The most common suggestions were: academic standards and rigour, deep reading and proficient writing, and engagement and empathy with the topic. Students, on the other hand, privileged engaging secondary sources, and engaging in discussion with academic staff in the classroom. Lowest ranked were working online (using the internet or email) and making a classroom or online presentation.

These responses were also analysed with reference to the open-ended accounts of the nature of historical thinking that students provided in response to Question One. Sixty-five per cent of all participating students included a reference to historical thinking as a process, sometimes agentic and sometimes routine and mechanical. They used terms such as analyse, evaluate, investigate, re-enact, compare and contrast and reflect and then a proportion of those also provided points of reference that shape these processes. These included: context, subjectivity, bias, structure, memory and empathy. The students' views are at times reflected by other stakeholders: staff, higher education policy-makers and researchers. At other times they can be seen to be at odds. This paper will examine four aspects that emerged from the data: evidence, assessment, engagement and online futures.

\section{INTERPRETING EVIDENCE}

The value of secondary sources in this study proved to be a disputed site. Students tend to associate them firmly with historical thinking and lecturers would rather promote primary sources first and, then, offer secondary sources as an accompanying historiographical narrative. Both groups were firmly anchored in these assertions. The data showed 63 per cent of all valid student responses ranked option three (Reading books and journal articles) in their top three, and it was the ranking that evoked the most agreement among all students (see Standard Deviation Table 3). In contrast 42 per cent of students ranked option 13 (Archival work, material evidence and field work) in the bottom three, and this was generally given a mid-range ranking by students, usually cited as the fifth or sixth most useful activity. Given that students had the option to rank as many, or as few, activities as they chose, it is notable that 81.5 per cent of students gave books and journals a valid ranking while archival work was only ranked by 63.3 per cent of participating students.

In light of the current literature and the interviews with lecturers, the apparent national trend by students to privilege secondary sources over primary sources must be of concern. Bailey demonstrated that evidence-based teaching is increasingly a focus of researchers (Bailey and Hughes-Warrington 2009). Mucher (2007) for example created a disciplinary tool that would create a 'culture of evidence' for children in primary and high schools. Similarly, Wineburg expresses a sense of urgency for re-evaluation of the way sources are used in high schools (Wineburg 1991: 518). As Booth has argued, however, there is no cohesive pedagogical progression between schools and universities (Booth 2005: 14). The findings in this project confirm Booth's concern: 


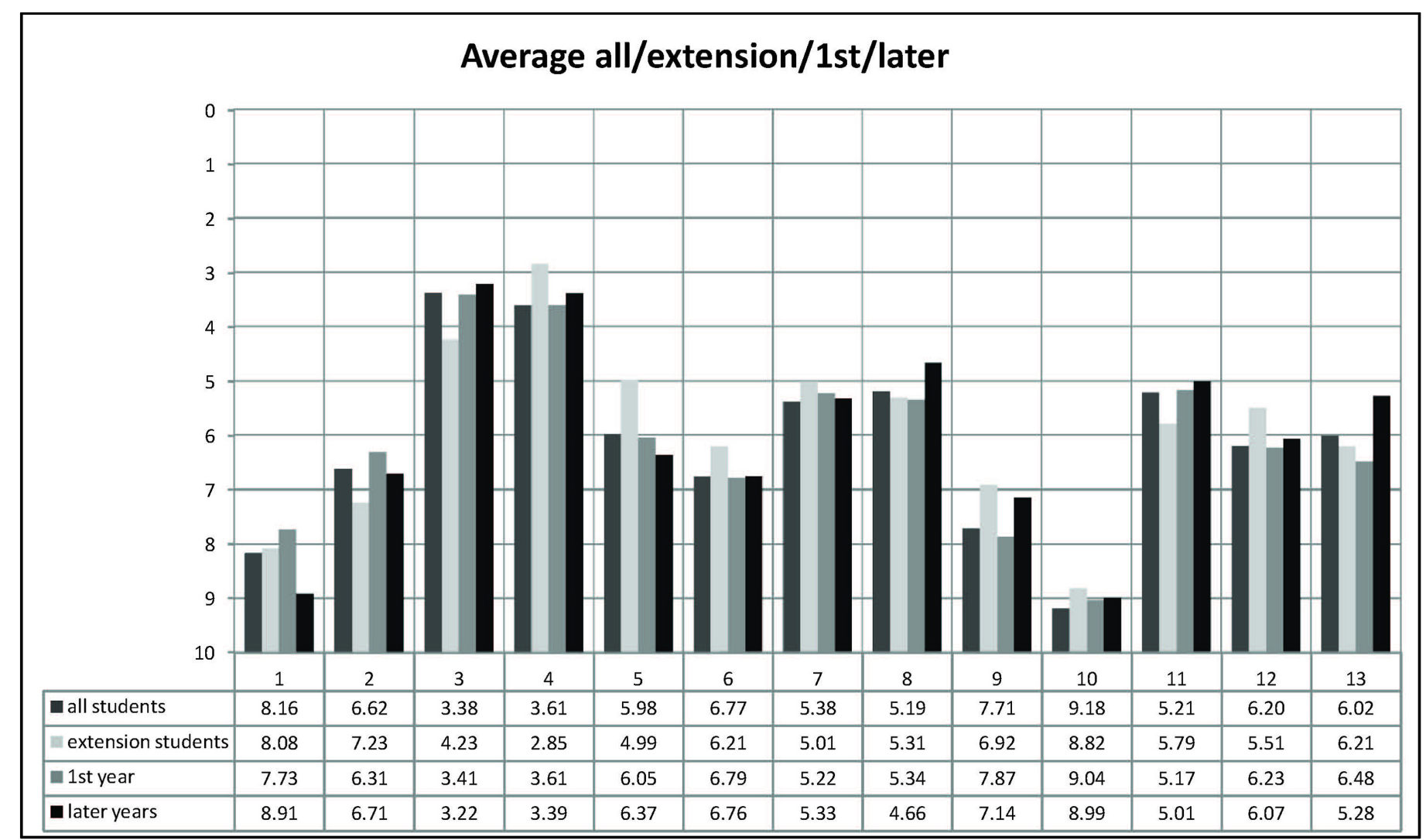

Figure 1: The average ratings by students of the 13 items (with the most useful ranked as 1 and the least useful as 13) 
the more complex engagement and location of the self as historian required for proper examination of primary sources appears less attractive than the ease of reading a secondary source.

Learning how to identify and use the different types of evidence was a priority in first year students' development according to lecturers. Almost without exception students are required to undertake some type of exercise that teaches them to differentiate between primary and secondary sources in the first weeks into a course. The complexities of this binary are then introduced slowly over varying periods of time according to individual lecturers' requirements or theoretical position. The disciplinary narrative lent heavily towards the discerning use of primary sources as the underpinning thread of practising history and this is mirrored in other studies such as Diaz et al. (2008: 1219). Yet students are not embracing this view or at least not seeing it at work in their learning activities. There is clearly a need for academics to express their views about evidence more explicitly with students, as they did in the interviews. As one respondent explains, for instance:
In first year we focus very much on primary source analysis and contextualising that and charting notions of change and continuity and trying to open up what we mean by history and what constitutes a historical subject and we also begin, we don't do a lot of it but we begin to analyse secondary sources so we begin to introduce them, though not to the extent that I would like, but we begin to introduce them to historiography. (Ind)

Among the lecturers there was a unanimous belief that learning to examine primary sources is a core skill requiring deep reading, contextualisation and empathy. Another two academics explain:

what we tend to do in first year is give them rich primary source materials and train them to read them without a text book. (IRU)

I don't set a huge amount of reading. But the reason I do that is quite deliberate because I make them engage with the internal logic of what they are reading and we do it slowly. We read very slowly. (G8)

The task is then one of orientation and interpretation. It is often a difficult process and an 'unnatural' one. As one lecturer says:

You can't be a good scholar, a good thinker or a good historian unless you actually synthesise something in your own language and make a place for it in the internal architecture of their brain. (G8)

Why do the students prefer a voice of interpretation and translation over the organic materiality of primary sources? Is this simply laziness or a lack of confidence? Were the students confused about the content of their unit hand outs and resource materials? Was primary evidence a 'taken for granted' component of history? Were some of the students still struggling with the difference between primary and secondary sources as conveyed by lecturers?

One way to look at the problem is to examine first year responses as compared to later years and in particular those students enrolled in history theory and method courses as precursors to post graduate studies. These students should not have any problems differentiating the two types 
of sources; indeed they would be versed to some degree in the problematic nature of all sources. Yet as Figure 1 shows, while there is a small shift away from secondary sources by methodology classes, the weight of their rankings has obviously gone to other options. Primary sources remain at a steady midway ranking for all groups.

\section{TEACHING AND ENGAGEMENT}

Students also associated engaging with academic staff in the classroom firmly with historical thinking (Figure 1), with 58.5 per cent of all students ranking it in their top three choices. On average, the first years and later years collectively ranked it as 3.6, although New South Wales extension students rated it higher with an average of 2.8. Given that students had the option to rank as many or as few activities as they chose, it is worth noting that 76 per cent of students gave it a valid ranking.

The lecturer or tutor is not only the guide or facilitator for the unit, they are also interpreters and the means by which the students bridge and contextualise the broader questions of history. They provide the answers to the question: 'Why do history?'

The lecturer or tutor is also the vehicle through which students gain confidence to speak and write about history. They are available to be used as experimental sound boards by students. The students rarely see themselves as being skilled or having the knowledge to engage in original debate. In the response to Question One of the questionnaire (What is historical thinking?) there were indications that even this later year student, studying methodology, had limited expectations of their role, stating historical thinking was:

Observing arguments, assessing sources (primary and secondary) and not necessarily making one's own judgment (at this level of study) but being able to pinpoint methods and problems of other historians.

Shifting students from the passive learner to engaged thinker is a task that must occur in lecture theatres and tutorial rooms, as an academic puts it:

I want them now to be much more active learners and I want to set them up in a scenario that they pursue in groups and individually and take them to a different place (IRU)

For some lecturers this is thought of as some sort of disorientation process, one which disrupts the boundaries between students and historians. It rests upon the ability of the student to rethink the imagined past, the evidence and themselves, as readers, thinkers, writers and active participants in history. Lecturers described the process as 'an imaginary leap', a need to 'develop a sense of a possibility of alterity' and as a sort of 'relativistic empathy'. These views echo some of the arguments put forward by Levstik (2001), VanSledright (2002), and Yeager and van Hover (2007).

\section{VEHICLES FOR ASSESSMENT AND SCHOLARSHIP}

There are deep divisions between staff and student perceptions of the value of assessment tasks and feedback for the development of historical thinking. Students drew few connections between completing assessment tasks and receiving feedback on them and historical thinking (Options 8, 
9, and 10). Table 3 in the appendix reveals that essays received mid range rankings while feedback and presentations were rated poorly. For academics, on the other hand, assessment and feedback form an important part of the development of students as historians. As one commented:

The skills that we try and engender in our students have to do with reading primary sources critically, mounting and developing an argument, synthesizing historiography, presenting ideas and doing so in a way that it draws in all those three areas. (G8)

The lecturers indicated in the interviews that their views are shaped by the institutions' generic rules, school or departmental policy and by individuals' philosophies about teaching. The latter involves modelling their approach based on their own undergraduate and postgraduate experiences in universities in Australia, Germany, Britain and the USA, on current research in education and on practical experimentation. In this section of the paper three aspects of assessment will be explored: writing essays, giving presentations and feedback.

\section{WRITING ESSAYS AND ASSIGNMENTS}

Students regarded essays and assignments to be mid range, most often ranking them as fourth or fifth in terms of importance to their development of historical thinking. Throughout the interviews there was a constant concern expressed by academics about the students' ability to write. In both the interview settings and in informal discussions, lecturers consistently commented that students' writing was not of a high enough standard, lacking sufficient basic practice in writing and a general sense of epistemological comprehension. As one explains:

We are entering an age where people are increasingly functionally illiterate.

You can tell they are not reading enough and they are not writing enough. So we are in an intellectual crisis in western society and frankly I don't think that is going to change. (G8)

Essays remain at the centre of all assessment models (Nye 2008). In recent decades what constitutes an essay has become more diversified and includes minor and major, reflective, critical and research essays. This is alongside a range of analysis exercises on documents or visual sources. Thus writing and constructing an argument remains a large proportion of assessment and lecturers see it as central to the development of historical thinking. Yet students have ranked this option with only moderate enthusiasm. This may also, in part, be due to students regarding essays merely as assessment - of pre-existing historical thinking - rather than as integral to the process of developing historical thinking.

\section{PRESENTATIONS}

Presentations are a contentious issue for students: most rate them poorly. Only 49.6 per cent of participating students even gave Option 10 a valid ranking. In contrast lecturers were divided and differed considerably in their philosophy and practice. The traditional format for presentations was for one or two students to present their interpretation of a particular problem to the group. Today they can include online presentations or interactive teaching systems. Giving a presentation in a tutorial is performative. Such presentations require confidence and empathy with both the 
audience and the subject matter. They encourage students to blur the boundaries between teaching and learning. They become problematic and impractical when tutorial sizes grow too large. Lecturers and tutors must then strike a balance between these epistemological and practical demands.

Four contrasting approaches to tutorial presentations demonstrate the diversity within the discipline:

I don't get them to do tute papers, mainly because I think they just kill every conversation. (G8)

There are no marks given for it at all but I think it is a good skill for them to learn. You can see how terrified they are of doing it but nobody ever says anything bad about their presentations. (Ind)

They essentially take over a tute, in a very hands on kind of way, and out of that comes an experience of working with other people, getting interesting and different approaches and different roles that they can play with in a project. (G8)

I'd have an anchor person lead a group for ten minutes and at the end of the ten minutes they all move on to the next group. So there is a rotation. The participants actually give feedback as where they have come to with the previous anchor person moves on with where they think the discussion should be going. (IRU)

It is evident from the literature, however, that contextualising the self as a thinker, writer and speaker on history is vital to the development of historical thinking. Making a presentation to one's peers is an important part of that organic process, particularly for those seeking a career as a researcher. Yet we cannot ignore the significantly low ratings students assigned to presentations. A balance needs to be found between institutional structural demands, the epistemological and pedagogical positions of the discipline, and student receptiveness.

\section{FEEDBACK ON ASSIGNMENTS}

Feedback on assignments was rated quite poorly by students with only 57.2 per cent of participating students giving it a valid ranking. For those who did rank it, there was a strong consensus with students ranking it, on average, as the seventh most useful activity. The constraints of many students' lives often mean that they will focus on the formula: what needs to be done to pass the course. The ideal of developing a cumulative knowledge of the subject area, through inter-connected assignments, can become lost in the realities of their broader life. Instead talk in the corridors of universities around the country followed the vein of 'I have three weeks and four essays to submit'. But these are more assumptions and generalisations than clearly evident trends. Indeed, some anecdotal evidence suggests that many students are unclear as to what constitutes feedback. Some students in this study, from three later-year classes, rated feedback considerably higher than most, thus breaking with the national trend. This might suggest that, as students' progress, they become more appreciative of the value of feedback. 
Lecturers, tutors and markers clearly indicated in this study that the combination of good feedback and a responsive student could produce significant progression in the development of historical thinking and writing. They argued that while it was a time-consuming process, there was little doubt that the benefits were evident. Such practices are not dissimilar to the formative supervision of postgraduates. As two academics explain:

We actually talk about what we have written and we share our drafts, we tend to give feedback which is summative of it whereas the real feedback they need is formative. (Ind)

Leading up to an essay, doing a synopsis, what they are doing first of all and having a look at those, they were not assessed but you have to put one in sort of thing, to see where they are going and to meet with them, it is very time consuming with big classes. (G8)

Looking to other research, the national annual survey by Universities Australia found a higher degree of approval for assessment. In the 2007 Graduate Experience Questionnaires, the national rate on 'Appropriate Assessment' scale by students who have graduated with a bachelor's degree in history indicated that 36.8 per cent of students strongly agreed and 34.8 per cent of students agreed that their assessment was appropriate. Only 8.7 per cent disagreed and 3.7 per cent strongly disagreed (UniversitiesAustralia 2008). The difference can be explained in part, because asking what is 'appropriate' in the graduate experience and what is 'useful to historical thinking' are different questions. Perhaps it is also the case, that while the students are within the system, assessment is an immediate and daily issue. By the time students have graduated, successfully navigated the requirements and met the criteria, they are less concerned.

The absence of a shared view among all the stakeholders towards assessment can be viewed as a productive site for disciplinary conversations. Each of the stakeholders hold different and situated priorities, goals and agendas. This study offered an opportunity to add the undergraduate student voice to the dialogue on assessment and scholarship between educationalists, history academics and the university teaching and learning committees.

\section{ONLINE FUTURES}

On a national level history students indicated that they did not think online activities assisted in their development of historical thinking. Using the internet and email (Option 1) and giving online or class presentations (Option 10) rated poorly, occupying the lowest ratings. The collective data from this project revealed differences between individual classes, between first and later students and amongst lecturers against a backdrop of the sector and institutional policy directives for the future.

For students differences were comparatively small but did provide some indications. In Table 2, for example, Flinders University students rated the online activities higher than any other university. This may well be reflective of the work being done at Flinders, which offers units exploring history and film. The second difference was seen in the standard deviation results which showed that later-year students were less unified in their rejection of online activities than firstyear students. 
Some lecturers raised the issue of the internal/external student divide, stating that they were encountering opposition from internal undergraduates to participate in online activities, as one explains:

We stay constantly in touch especially with externals in particular. The internals rarely use it all. You have to twist their arm to get them to go on it at all. I am actually putting some of their material up on a fortnightly basis, so they have to visit the site. And that was deliberately done so they have to visit the site. (Ind)

Others relayed stories of positive experiences with online activities such as short pre-tutorial quizzes, where internal students competed against themselves and each other for perfect scores and tutors felt assured that students had done adequate reading for the tutorials:

I got frustrated with people not doing the readings and introduced a weekly online quiz which is multiple choice and very quick, which they have to do every week before the main lecture of the week. That examines them on that week and the lecture before to keep them awake so [sic] but it is multiple choice so they always have a chance of one in five. But strangely they have been taking it incredibly seriously, more than they probably should and they are getting, many of them got into a competition to never have anything wrong. So I think that worked fairly well. (G8)

A further aspect of this analysis is the sector and institutional intention to see a broad digitisation of education. While lecturers appear to accept this online future and blended learning as inevitable, its shape and the mechanics of this process, for many, remain somewhat of a mystery. As one lecturer pointed out:

Well that is what the university is looking at, we have all got to go online, by 2010, nearly every unit, first year units go online and as technology improves we should conduct collective tutorials if you like, probably even see each other, well the students will be able to see the lecturer, I dare say, and we have to do that because all universities are getting into distance education. (Ind)

These findings raise many questions about the shape of online teaching within the history discipline in the future. There is a need to examine how to make the most of the tools we will have at our disposal and how to match them to pre-existing pedagogical concerns and goals. Thus it would be useful to look at areas such as evidence-based teaching, effective student/teacher engagement and assessment strategies.

\section{CONCLUSIONS}

Researching students' perceptions of the nature of historical thinking highlights points of convergence with and divergence from staff views. When asked which specific activities most enhance one's development in historical thinking, a remarkable national trend emerged. The data showed that students across the country shared largely similar views, including the privileging of secondary 
sources over primary sources and a less than enthusiastic response to current assessment strategies and online work. Only in varying degrees are they locating themselves in the disciplinary dialogue. Each of these aspects is crucial to a development of historical thinking in students.

Questions of evidence have been privileged by all stakeholders in higher education in differing ways. Researchers in history education such as Seixas, Diaz et al and Wineberg confirm that evidence and ways for interpreting it are problematic but crucial to understanding history, the discipline and its context. Lecturers overwhelmingly prioritised evidence in the narrative of the skills for historical thinking. They listed the difference between primary and secondary evidence, the skills required to read and analyse it and how then to offer an interpretation. Students were also largely thinking about evidence but with a focus on secondary sources: books and journals.

Online teaching and learning emerged as an area of potential underdevelopment in this study. Students rated it poorly and lecturers ranged from being involved in extensive online work to almost none at all. Sector-wide reports, such as the Review of Australian Higher Education Report (Bradley et al. 2008: 79), point to a more extensive implementation of online teaching and learning. It was evident in this study that more research into the (dis)connections between online work and student engagement would be valuable. Such undertakings could develop strategies that advance the development of historical thinking, meet the scholarly requirements of history teaching and embrace student expectations as well as reflect the disciplinary culture and sector wide requirements.

Throughout this study it was obvious that many academics are thinking regularly about assessment strategies, researching the field, participating in discussions and committee groups and implementing experimental practices in their classes. Further exploration would be timely, to not only record and investigate the innovative ideas but to promote further thinking and experimentation among educators. 


\section{APPENDIX}

\begin{tabular}{|c|c|c|c|c|c|c|c|c|c|c|c|c|c|}
\hline & 01 & 02 & 03 & 04 & 05 & 06 & 07 & 08 & 09 & 010 & 011 & 012 & 013 \\
\hline UWA & 9.1 & 6.8 & 3.2 & 3.7 & 6.8 & 6.9 & 4.9 & 4.9 & 7.0 & 8.5 & 5.7 & 6.3 & 6.6 \\
\hline UTAS & 8.4 & 6.8 & 3.1 & 3.4 & 5.5 & 6.9 & 5.5 & 4.6 & 7.4 & 9.9 & 4.4 & 7.0 & 6.2 \\
\hline USYD & 8.1 & 7.7 & 3.4 & 3.6 & 6.0 & 6.9 & 5.2 & 4.4 & 7.3 & 9.2 & 5.9 & 5.9 & 5.7 \\
\hline UQ & 7.7 & 6.4 & 3.2 & 3.1 & 6.2 & 7.1 & 5.2 & 4.7 & 8.0 & 9.3 & 5.1 & 5.9 & 5.6 \\
\hline UNSW & 7.5 & 6.3 & 3.2 & 3.7 & 5.8 & 7.0 & 5.3 & 5.4 & 7.8 & 8.7 & 5.2 & 6.1 & 5.5 \\
\hline UNE & 7.9 & 7.9 & 3.5 & 3.8 & 5.6 & 6.7 & 5.8 & 5.7 & 7.8 & 9.7 & 4.9 & 6.2 & 5.8 \\
\hline Melb & 8.2 & 6.7 & 3.4 & 3.7 & 5.7 & 5.9 & 4.8 & 5.0 & 8.1 & 9.4 & 5.6 & 5.6 & 6.6 \\
\hline MO & 7.7 & 5.9 & 3.2 & 3.7 & 5.9 & 6.4 & 5.1 & 5.3 & 7.5 & 8.9 & 4.9 & 5.6 & 6.1 \\
\hline La Trobe & 9.0 & 7.0 & 3.4 & 3.4 & 5.9 & 5.6 & 5.3 & 5.7 & 7.0 & 10.2 & 4.5 & 6.5 & 5.1 \\
\hline Flinders & 7.3 & 5.8 & 3.8 & 3.8 & 5.9 & 7.0 & 5.7 & 5.3 & 8.5 & 8.4 & 4.7 & 6.7 & 6.2 \\
\hline ANU & 8.3 & 5.9 & 3.2 & 3.2 & 6.0 & 7.6 & 5.8 & 5.6 & 8.0 & 8.4 & 5.8 & 5.8 & 6.1 \\
\hline Option 1 & \multicolumn{13}{|c|}{ Working Online (using the internet or email). } \\
\hline Option 2 & \multicolumn{13}{|c|}{ Watching and discussing film and television. } \\
\hline Option 3 & \multicolumn{13}{|c|}{ Reading books and journal articles. } \\
\hline Option 4 & \multicolumn{13}{|c|}{ Engaging in discussion with academic staff in the classroom. } \\
\hline Option 5 & \multicolumn{13}{|c|}{ Informal discussions with academic staff outside of the classroom. } \\
\hline Option 6 & \multicolumn{13}{|c|}{ Engaging in discussion with fellow students outside of the classroom. } \\
\hline Option 7 & \multicolumn{13}{|c|}{ Engaging in discussion with fellow students in the classroom. } \\
\hline Option 8 & \multicolumn{13}{|c|}{ Working on an essay or assignment. } \\
\hline Option 9 & \multicolumn{13}{|c|}{ Receiving feedback on assignments. } \\
\hline Option 10 & \multicolumn{13}{|c|}{ Making a classroom or online presentation. } \\
\hline Option 11 & \multicolumn{13}{|c|}{ Attending a lecture. } \\
\hline Option 12 & \multicolumn{13}{|c|}{ Having conversations with others who have very different opinions or values. } \\
\hline Option 13 & \multicolumn{13}{|c|}{ Archival work, handling material evidence or engagement in field work. } \\
\hline
\end{tabular}

Table 1 Table indicating the shared views of students from each university. A ranking of 1 indicates the most useful.

\begin{tabular}{|l|l|}
\hline Group of $8(\mathrm{G} 8)$ & $\begin{array}{l}\text { Australian National University, University of Sydney, University of } \\
\text { New South Wales, University of Melbourne, Monash University, } \\
\text { University of Western Australia }\end{array}$ \\
\hline Innovative Research Universities (IRU) & Flinders University, La Trobe University \\
\hline Independents (Ind) & $\begin{array}{l}\text { Macquarie University, University of New England and University of } \\
\text { Tasmania }\end{array}$ \\
\hline
\end{tabular}

Table 2 Interviewees are identified by their (non) membership of University Networks 


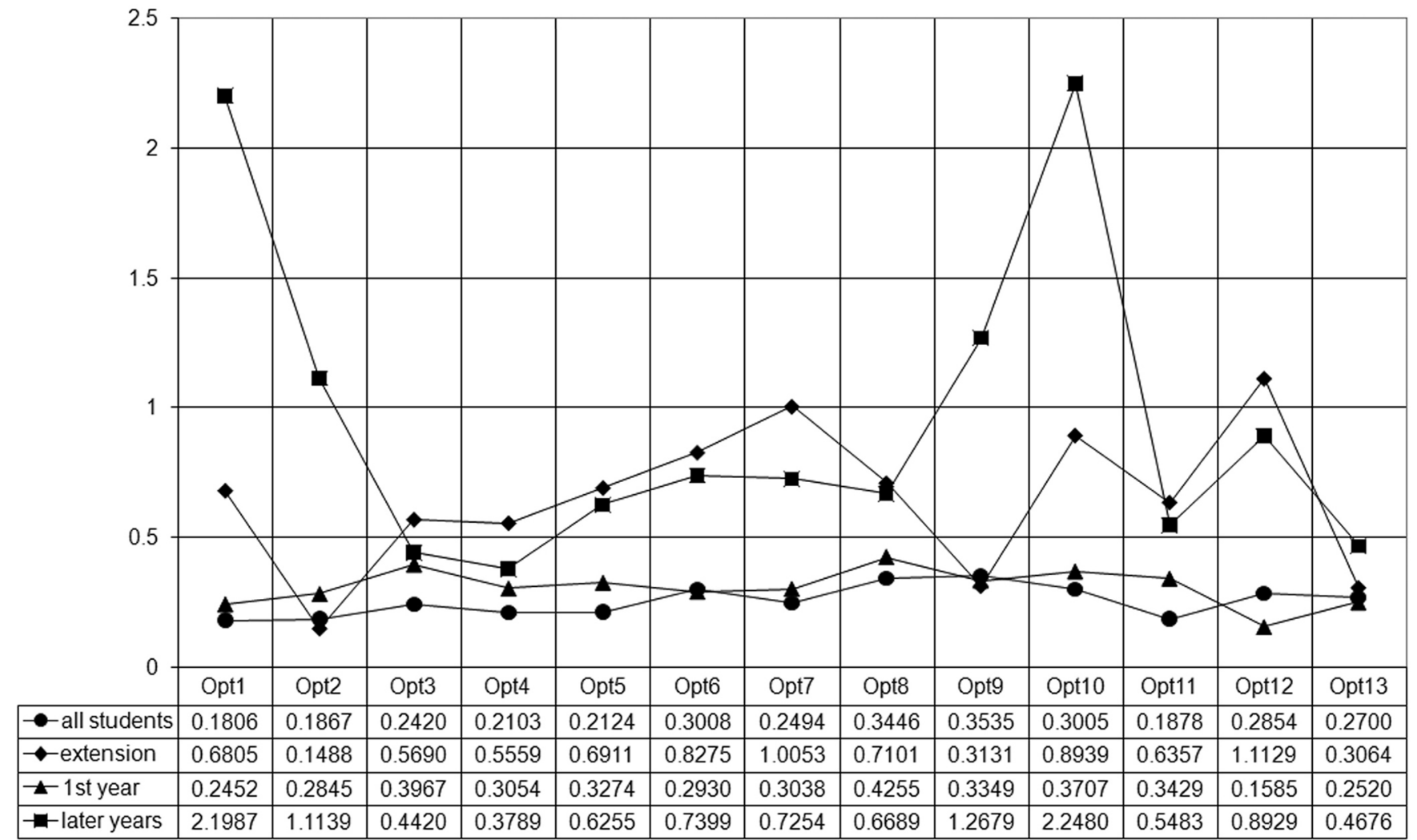

Figure 2: Standard Deviation: The lower results indicate that the students were more unified in their views. High results in turn indicate the diversity and dissention. 


\begin{tabular}{|l|l|l|}
\hline Options & $\begin{array}{l}\text { Highest } \\
\text { Rankings }\end{array}$ & $\begin{array}{l}\text { Lowest } \\
\text { Rankings }\end{array}$ \\
\hline 1. Working Online (using the internet or email) & Flinders & UWA \\
\hline 2. Watching and discussing film and television & Flinders & USYD \\
\hline 3. Reading books and journal articles & ANU & Flinders \\
\hline 4. Engaging in discussion with academic staff in the classroom & UQ & UNE \\
\hline 5. Informal discussions with academic staff outside of the classroom & UTAS & UWA \\
\hline 6. Engaging in discussion with fellow students outside of the classroom & La Trobe & ANU \\
\hline 7. Engaging in discussion with fellow students in the classroom & Melbourne & ANU \\
\hline 8. Working on an essay or assignment & USYD & La Trobe \\
\hline 9. Receiving feedback on assignments & UWA & Flinders \\
\hline 10. Making a classroom or online presentation & ANU & La Trobe \\
\hline 11. Attending a lecture & UTAS & USYD \\
\hline 12. Having conversations with others who have very different opinions or values & MO & UTAS \\
\hline 13. Archival work, handling material evidence or engagement in field work & La Trobe & Melbourne \\
\hline
\end{tabular}

Table 3 The highest and lowest rankings made by students of individual universities

\begin{tabular}{|l|c|c|c|}
\hline Students & Essays & Feedback & Presentation \\
\hline 1st Years & 5.0 & 8.0 & 10.0 \\
Later & 4.0 & 7.5 & 9.0 \\
Extension & 5.0 & 6.5 & 9.5 \\
\hline
\end{tabular}

Table 4 National Median results for Assessment (Scale 1-13)

\section{REFERENCES}

Bailey, Matt; Hughes-Warrington, Marnie. 2009. 'A literature review of 'Historical Thinking'. Teaching History 43 (2) (June): 13-15.

Booth, Alan. 2005. 'Worlds in collision: University tutor and student perspectives on the transition to degree level history'. Teaching History 121: 14-19.

Bradley, Denise; Noonan, Peter; Nugent, Helen; Scales Bill. 2008. 'Review of Australian higher education: Final report'. Canberra: Department of Education, Employment and Workplace Relations.

Diaz, Arlene; Middendorf, Joan; Pace, David; Shopkow, Leah. 2008. 'The history learning project: A department "decodes" its students'. Journal of American History 94 (4): 1211-1224.

Haraway, Donna. 1988. 'Situated knowledges: The science question in feminism and the privilege of partial perspective'. Feminist Studies 14 (3): 575-599.

Kemmis, S.; McTaggart, R. 2000. 'Participatory action research'. In Handbook of Qualitative Research, edited by Denzin, N.K.; Lincoln, Y.S. California: Sage: 567-605.

Lee, Peter; Ashby, Rosalyn. 2001. 'Empathy, perspective taking and rational understanding'. In Historical Empathy and Perspective Taking in the Social Studies, edited by Davis, O.L.; Yeagher. Elizabeth Anne; Foster, Stuart J. Lanham: Rowman and Littlefield: 21-50.

Levstik, Linda. 2001. 'Crossing empty spaces: New Zealand adolescents' conceptions of perspective-taking and historical significance'. In Historical Empathy and Perspective Taking in the Social Studies, 
edited by Davis, O.L.; Yeager, Elizabeth Anne; Foster, Stuart J. Lanham: Rowman and Littlefield: 69-96.

Mucher, Stephen. 2007. 'Building a culture of evidence through professional development'. The History Teacher 40 (2): 265-273.

Nye, Adele. 2008. 'Learning outcomes in history: An analysis of online statements from history departments in Australian universities'. Unpublished paper prepared for the 'Historical Thinking in Higher Education' Project Team and Steering Committee. August 2008.

Rüsen, Jorn. 2005. History: Narration Interpretation Orientation. Oxford: Berghahn Books.

Seixas, Peter, ed. 2006. Theorizing Historical Consciousness. Toronto: University of Toronto Press.

UniversitiesAustralia. 2008. Graduate Careers Australia 2007 Course Experience Questionnaire Tables. Canberra: UniversitiesAustralia.

VanSledright, Bruce A. 2001. 'From empathetic regard to self-understanding: Im/positionality, empathy, and historical contextualization'. In Historical Empathy and Perspective Taking in the Social Studies, edited by Davis, O.L.; Yeager, Elizabeth Anne; Foster, Stuart J. Lanham: Rowman \& Littlefield: 51-68.

Wineburg, Samuel. 1991. 'On reading historical texts: Notes on the breach between school and the academy'. American Educational Research Journal 28 (3): 495-519.

Wineburg, Samuel. 1999. 'Historical thinking and other unnatural acts'. Phi Delta Kappan 80 (7): 488-499.

Wright, Handel. 2006. 'Are we (t)here yet? Qualitative research in education's profuse and contested present'. International Journal of Qualitative Studies in Education 19 (6): 793-802.

Yeager, Elizabeth; van Hover, Stephanie. 2007. "I want to use my subject matter to..." The role of purpose in one U.S. secondary history teacher's instructional decision making'. Canadian Journal of Education 30 (3): 670-690.

Cite this article as: Nye, Adele; Hughes-Warrington, Marnie; Roe, Jill; Russell, Penny; Peel, Mark; Deacon, Desley; Laugeson, Amanda; Kiem, Paul. 2009. 'Historical thinking in Higher Education: Staff and student perceptions of the nature of historical thinking'. History Australia 6 (3): pp. 73.1 to 73.16. DOI:

10.2104/ha090073. 